\title{
HUMAN RESOURCES CHALLENGES FOR THE NEXT 10 YEARS: CASE STUDY OF TURKEY
}

\author{
Ayse Gunaltay ${ }^{1}$, Ugur Filiz ${ }^{2}$ \\ ${ }^{1}$ Doctoral School of Enterprise Theory and Practice, University of Miskolc, ${ }^{2}$ Doctoral School of Economic and \\ Regional Sciences, Hungarian University of Agriculture and Life Sciences
}

\begin{abstract}
Today, it is critical for businesses to utilize their resources to gain and sustain competitive advantage by having skilled workforce, retaining, and using employees in line with their business objectives and strategies. Therefore, possession of skilled workforce is recognized as one of the determining factors in the success of enterprises in today's competitive environment. It is important to emphasize that this can be achieved only with effective management policies and practices. The concept of globalization will not be missing within next 10 years considering that it has been one of the most important phenomena of the recent decades. In this context, human resources managers, who continue to remain "local" in terms of their knowledge and experience, need to improve themselves by learning new markets, new legislation, new cultures and different norms required by the changing business conditions. In the past, while practices known as employee record keeping, social work duty, personnel management were constituting the main understanding of Human Resource Management (HRM), following the industrial relations, HRM processes have started to be subject to major change and transformation. Currently, HRM has become a critical topic for the organizations due to its significance and impact on their strategic management. Within this context, application, and transformation of HRM is the focus of this study within the projections about its future considering the potential problems may have been encountered during this transformation process. Therefore, this study will examine the difficulties and challenges that may be experienced by HR managers within the next 10 years. Firstly, the current problems of HRM and the main discussions on this subject in the literature will be examined together with the predictions for the next 10 years. Later, in line with the survey results conducted to the HR managers in the Istanbul region, the discussions in the literature will be compared with the predictions of the local HR managers. Considering the complexity of human resources that derives from its own nature and the environment in which it operates, the everyday challenges experienced by HR professionals while handling their routine tasks should be discussed thoroughly by encouraging everyone to share their ideas and to put their best effort to improve their HR processes, policies, and practices.
\end{abstract}

KEYWORDS: human resources management, performance management, talent management, the future of human resources management, HRM.

JEL CLASSIFICATION: M12, M50, M51, M52, M54

\section{Introduction}

Ensuring coordination and integration among human capital management and business strategies is one of the main issues for organizations during the management process of their human resources (HR). Therefore, it is important to put customer and result-oriented approaches at the centre of execution of human capital plan and programme, as well as business strategies in all organizations. Another important issue is the lack of organizing human resources in a way that will lead to achieving significant business results. Also, lack of vision of line managers regarding human capital can be given as another issue within this context. The main question in the paradigm about transformation of human resources experienced today is how human resources practices can create business value and added value.

Boudreau and Ramstad (2007) have provided an answer for this question by comparing the new mission statement with the traditional paradigm. The traditional point of view emphasizes that the HR function is based on the understanding of providing excellent services to help the management of people who are recognized as the most important asset of companies. The new paradigm recognizes human resources as a key factor in enhancing the success of the organizations by improving the decisions that affect people or depend on people. From this point of view, while the traditional paradigm had a "product-based" view by defining the value proposition based on providing high quality services to meet the needs of the buyers; the new paradigm has revealed a "solution based" approach as opposed to the productbased approach.

In the literature, there are a wide range of studies with findings on this topic which suggest the competitive power of organizations can be enhanced by developing high-performance work systems that help organizations accomplish their strategic business objectives (Datta et al., 2005; Wright \& Boswell, 2002). The most important part of having a competitive advantage ensured by human resources is that other organizations cannot easily imitate this factor due to its unique character that is not based on financial and strategic metrics (Luthans \& Youssef, 2005)

Within the context of the future of human resources, there are questions regarding whether human managerial or strategic roles should be assigned to Human Resources Management (HRM) as well as regarding the issue of how to clearly define roles and obligations of HR professionals during upcoming years. According to Delery and Shaw (2001), a strategic approach to HRM requires focusing on the strategic role of human resources in improving the effectiveness of organizations through business-unit or organizational level analysis. Therefore, the human resources function should effectively support any decisions that needs to be taken by considering the human capital because the sustainability of competitive advantage is a critical issue for all organizations that is possible with unique skills and competencies of their 
human capital (Becker \& Gerhart, 1996). Boudreau and Ramstad (2007) argued that with the increase in the intellectual level of human resources stakeholders, their importance will also increase as a strong strategic partner. At this point, human capital management should play an important role for organizations as a strategic partner since human resources are critical in the process of developing their business strategies and objectives. The important issue here is to establish a strong link between organizational strategy and capabilities of human resources (Ziskin and Boudreau, 2011). Also, it is necessary to create a HR system that will benefit from the employees by improving their performance, productivity, skills, and commitment (Levine, 1995; Pfeffer, 1998).

Another dimension that needs to be addressed in order to transform human resources practices is the question of how this transformation will take place within the organizations (Ulrich and Brockbank, 2009). The key point in the answer to this question has been closely related to establishing a relationship between business strategies and human resources practices. On this topic, Amit and Belcourt (2000) examined the relationship between organizational strategies and human resources and evaluated the potential role of HRM in realizing the market strategies of organizations and achieving their business objectives. Accordingly, they stated that if the human resources have an effective and strong position in the general strategies of the organization, the financial performance of the enterprise will also be positively affected. Fink and Longenecker (2009) emphasized that effective human resources should be understood in terms of achieving managerial strategic goals and their contribution to the organization's value chain and workforce in executing the business strategy. In other words, designing a HR system has significant strategic implications for the organizations due to its unique characteristics specializing in human resources (Amit and Shoemaker, 1993). In order to have an effective HR system, executives other than human resources should have a decent level of knowledge on issues such as nurturing talent development, creating result-oriented performance management and valuation systems, handling wage and incentive systems together.

To summarize, we can discuss the main issues and challenges faced by today's human resources under two topics. The first main issue is regarding the current position of the HR department due to its insufficiency in terms of the development and implementation of $\mathrm{HR}$ policies and practices. In the human resources literature, it is emphasized that HR departments and HR managers should play a more important role in the business strategies. Another important issue is the integration of HR plan and programmes into the general strategies of the company in relation to the first problem or, in other words, regarding how HR strategies can be included in the creation process of the business strategies. In this regard, in the literature, the integration of general business strategies of the organization and the strategy development processes from the perspective of human resources are discussed within context of how it can increase organizational performance. In the following sections, we will examine how the future predictions are made in the literature within the framework of the main problems faced by HRM in the organizations today.

\section{Literature Review}

HRM field has been subject to major transformations due to some factors such as a shift in the economic prosperity, increasing globalization, rising domestic diversity and advancement in technology, and it is forced to change and adopt to these ongoing changes (Stone and Deadrick, 2015). According to Andersen and Minbaeva (2013), evaluating the future of HR function should help improve management of organizations through development of effective HR practices and competencies. Two basic and original processes assist management in supporting HR business objectives and realizing the business values that derive from HR functions. The first process is designing the management processes of companies with humanitarian strategies while the second is the development of human resources strategies in a way that will support the general business strategies. According to the current and future comparisons on the time spent by human resources, an increase from $10 \%$ to $35 \%$ in strategic human resources planning, an increase from $25 \%$ to $50 \%$ in consultancy/development, and a decrease from $65 \%$ to $25 \%$ for executive and managerial issues are predicted. With this foresight, it is emphasized that HR employees should also improve their competencies and skills continuously. As stated by Beer (1997), the concepts of talent and capability management within the business can especially be taken into consideration at the executive levels within the basis of future foresight in human resources.

Another prediction regarding the future of human resources is that human resources will become a consultancy in a coordinated relationship with the business and external environment in the light of their value creation role. In this regard, Ulrich and Brockbank (2005) developed a model for human resources value proposition. The model includes recognizing the external factors in business environment, serving internal and external stakeholders by creating HR applications and utilizing HR professionals.

However, Andersen and Minbaeva (2013) argued that while there are many discussions regarding the strategic role of HRM, there is not enough focus on HR activities that increase the effective execution of company strategies. Wright and Snell (2005), on the other hand, based on their future prediction, ask the question "Are human resources at a crossroads?". Besides, they stated that human resources have difficulties in creating value, they also emphasized that in order to be included in the value creation process, human resources must be in a key position and equipped appropriately to direct and address the critical issues of the businesses. Cascio (2005) stated that it is necessary to have some basic competencies regarding this value creation process. In his HR role model proposal, he emphasized the importance of knowing the business model of organizations, having basic business knowledge, a command of functional knowledge in HR field, the ability to listen and strategic business partnership. He also stated that the management of businesses over time will be undertaken by an 
organizational obligation in relation to business partnership. Armstrong (2005) in this discussion provided information on how to demonstrate step-by-step business partnerships that HR professionals should be in charge of designing policies and practices with elite behaviour that will lead to a sustainable success for businesses.

The first study on what the future of human resources would be is the study commissioned by Boston Consulting Group in 2010. The Boston Consulting Group (2010) asked some questions regarding the problems that could be encountered in the period of human resources until 2015 based on the observation of 1355 senior executives in 27 countries in Europe. In this study, the most critical and challenging human resources areas such as managing talent, managing employee demographics, creating a learning organization, managing work-life balance, managing change and cultural transformation, mastering human resources processes and restructuring organizations were noted as of little importance in the future by the participants.

Under the leadership of the Society for Human Resource Management (2010), the future of human resources was discussed at the leader's desk meeting with authors who hold an important position in HR field. While the participants emphasized that they focus more on risks, rapid globalization, benefits more from data and analytics, in most organizations it was found that HR functions had deficiencies in important capabilities. Accordingly, managerial support for talent management was regarded critical for the success of human resources as well as for increasing importance of talent and performance management (Aghazadeh, 2003). It was agreed between the authors that human resources need to leverage more data and analytical approaches that will lead to the better creation of the future global workforce. The main view was that the effective positioning of the HR function in the business environment will increase parallel to the increasing importance of human resources on the total performance of organizations.

\section{Purpose of the Research}

In this research, the difficulties that await human resources managers in the next 10 years, possible developments and their reactions in this context are investigated. In order to get more accurate results, a survey was carried out among the employees who work in HR departments of enterprises operating in the city of Istanbul. As a result of the study, the path that HRM will follow in the future, the consistency of the policies that it should follow with regards to the business environment will be discussed and the results will help us shape our future perspective. This study should provide a contribution to not only understanding the future impact of HR but also enlightening the future path of HR executives.

\section{Research Methodology}

Within the scope of the research methodology, the hypotheses, population and sample of the research, the data collection tool and the analysis of data will be discussed in this section.

Confidence interval accepted in the research is $95 \%$. Accordingly, the $\mathrm{t}$ value in the formula is 1.96. The incidence ( $\mathrm{p}$ value) of the investigated event was taken as 0.5 , and considering it was an exploratory study, the sampling error (d) was determined as 9\%. In the calculation made according to the formula, the number of questionnaires to be applied in the research was 96. At the end of the research, 100 questionnaires were evaluated. In order to reach sampling, the responses given to the questionnaires were collected from the enterprises by e-mail.

Two main research methodologies were used in this study. The first was theoretical analysis that consisted of reviewing and analysing national and international scientific studies on the subject that were used to form the theoretical structure of the study. The second research methodology was the empirical research that is collected with a questionnaire consisting of closed-ended questions. The first 4 questions of the survey were demographic questions. Ordinal-scale questions were included in the other 8 questions to determine the challenges of human resources that will potentially be experienced in the next 10 years. Therefore, the responses given to these ordinal options by the respondents should show the potential challenges that businesses may face in the next 10 years to some extent. In the preparation of the questionnaire form, the above written theoretical discussions are used, and the research is tested with a small-scale pilot application.

The data collected through the questionnaire is evaluated in the statistics analysis programme SPSS. First, the answers given to demographic questions are interpreted as numbers and percentages. Then, to test the developed study hypotheses, the responses given to the relevant questions are analysed with ordinal analysis method, and the relationship and significance between demographic factors and the perspectives of human resources in the next 10 years are revealed.

\section{Research Hypotheses}

In this research, ordinal question types are asked from the respondents to identify the challenges that human resources managers will face in the next 10 years. Within this framework, the following hypotheses have been created in order to reveal a relationship between the responses provided by HR managers and different sectors and different field of their business activities.

H1: There is a significant difference between the sectors in which the activity is performed and the difficulties that human resources managers will face.

$\mathrm{H} 2$ : There is a significant difference between the views of human resources managers on the difficulties they will face in the activities of the enterprise. 


\section{Research Findings}

The characteristics of the sample group participating in the research (sector, number of employees, field of activity, geographic field of study) are given in Figure 1.

Figure 1. Demographic Characteristics of Businesses

\begin{tabular}{|c|c|c|c|}
\hline \multicolumn{2}{|l|}{ Features } & $f$ & $\%$ \\
\hline \multirow{5}{*}{ Sector } & Service & 24 & 23.5 \\
\hline & Production & 51 & 50.0 \\
\hline & Public & 5 & 4.9 \\
\hline & Other & 20 & 21.6 \\
\hline & Total & 100 & 100.0 \\
\hline \multirow{6}{*}{$\begin{array}{l}\text { Number of } \\
\text { Employees }\end{array}$} & $1-249$ & 46 & 45.1 \\
\hline & $250-499$ & 12 & 11.0 \\
\hline & $500-749$ & 8 & 7.8 \\
\hline & $750-999$ & 8 & 7.8 \\
\hline & 1000 and more & 26 & 28.3 \\
\hline & Total & 100 & 100.0 \\
\hline \multirow{4}{*}{$\begin{array}{l}\text { Field of } \\
\text { Activity }\end{array}$} & Regional & 29 & 31.4 \\
\hline & National & 24 & 22.6 \\
\hline & International & 47 & 46.0 \\
\hline & Total & 100 & 100.0 \\
\hline \multirow{5}{*}{$\begin{array}{l}\text { Geographical } \\
\text { Field of Study }\end{array}$} & One factory in one geographic area & 41 & 42.7 \\
\hline & $\begin{array}{l}\text { Multiple factories in one geographic } \\
\text { area }\end{array}$ & 19 & 21,2 \\
\hline & $\begin{array}{l}\text { Numerous factories in the international } \\
\text { arena }\end{array}$ & 35 & 36.5 \\
\hline & Free & 5 & 4.9 \\
\hline & Total & 100 & 100.0 \\
\hline
\end{tabular}

Figure 1 shows that $51 \%$ of the respondents were from the production sector while $23.5 \%$ from the service sector, $21.6 \%$ from other sectors and $4.9 \%$ from the public sector. Considering the number of employees of the enterprises participating in the survey, $45.1 \%$ of enterprises had 1-249 employees, $28.3 \%$ of the enterprises 1000 employees and above, $11.0 \%$ between 250-499 employees, $7.8 \%$ between 500-749 employees and $7.8 \%$ of the enterprises had 750-999 employees. When the field of activity of the enterprises participating in the survey is examined, $46.0 \%$ of the enterprises are found to be operating in the international area, $31.4 \%$ in the regional arena and $22.6 \%$ in the national area. Geographically, $42.7 \%$ of the enterprises carry out their activities in a single geographical area with a single factory, $36.5 \%$ of them have numerous factories in the international area and the remaining $21.2 \%$ have more than one factory in a single geographical area.

Figure 2. Challenges that human resources will face in the next 10 years

\begin{tabular}{|c|c|c|c|c|c|c|c|}
\hline \multicolumn{4}{|c|}{$\begin{array}{l}\text { The challenges human resources will face in } \\
\text { the next } 10 \text { years }\end{array}$} & \multirow{2}{*}{$\begin{array}{c}\text { Kruskal } \\
\text { Wallis } \\
\text { Test in } \\
\text { terms of } \\
\text { industry }\end{array}$} & \multirow{2}{*}{$\begin{array}{c}\text { Kruskal } \\
\text { Wallis Test } \\
\text { in terms of } \\
\text { industry }\end{array}$} & \multirow{2}{*}{$\begin{array}{c}\text { Kruskal } \\
\text { Wallis } \\
\text { Test in } \\
\text { terms } \\
\text { of field } \\
\text { of } \\
\text { activity } \\
\text { Chi- } \\
\text { Square }\end{array}$} & \multirow{2}{*}{$\begin{array}{c}\text { Kruskal } \\
\text { Wallis Test } \\
\text { in terms of } \\
\text { field of } \\
\text { activity }\end{array}$} \\
\hline Features & Average & \begin{tabular}{c|} 
Kolmogorov \\
Smirnov Z \\
Test
\end{tabular} & $\begin{array}{l}\text { Significance } \\
\text { Level }\end{array}$ & & & & \\
\hline 1 & 3.32 & 1.754 & 0.004 & 8.405 & 0.037 & 0.47 & 0.786 \\
\hline 2 & 4.20 & 1.53 & 0.02 & 2.217 & 0.528 & 7.55 & 0.022 \\
\hline 3 & 3.92 & 1.757 & 0.004 & 15.260 & 0.003 & 0.021 & 0.987 \\
\hline 4 & 4.10 & 1.944 & 0.001 & 1.107 & 778 & 5.328 & 0.06 \\
\hline 5 & 4.58 & 1.494 & 0.023 & 14.532 & 0.002 & 6.467 & 0.038 \\
\hline 6 & 6.63 & 2.152 & 0 & 1.863 & 0.601 & 9.668 & 0.007 \\
\hline 7 & 5.7 & 1.318 & 0.062 & 0.609 & 0.896 & 5.325 & 0.067 \\
\hline 8 & 6.15 & 1.799 & 0.003 & 5.118 & 0.162 & 1.226 & 0.542 \\
\hline 9 & 6.58 & 1.731 & 0.005 & 6.373 & 0.094 & 0.602 & 0.73 \\
\hline
\end{tabular}

List of Features in Figure 2:

1. Best employee retention and reward

2. Leaders who will carry business into the future.

3. Organizational culture that will bring the best employees.

4. Skilled employees in the areas of expertise that are needed more.

5. Creating smooth and effective HR processes

6 . Finding the right people in the right markets

7. Inadequacy of HR processes in the direction of future generations

8.Carrying out HR processes and organizational processes and strategies together

9. Inadequacy of human resources processes in directing future generations.

In Figure 2, the issues that human resources will face in the next ten years are given in terms of difficulties. One Sample Kolmogorov-Smirnov Test is used to determine the order of the challenges that human resources will face in the next decade. Based on the figures, the following interpretations can be made:

- Participants stated that the greatest challenge human resources will face in the next decade is "retaining and rewarding the best employees". In other words, we can say that the issue of retaining the best employees will be the most difficult issue for human resources managers in the future.

- Participants of the survey stated "creating an organizational culture that will attract the best employees to the organization" as an important challenge in the 2nd place, "staying competitive in the talent market" as the $3^{\text {rd }}$ most important issue, "developing the leaders that will carry the company to the future" as the 4th most important among the difficulties they will face during next 10 years. Here, finding and retaining the best employees are given as one of the main challenges as well.

- Among the respondents of the questionnaire, the 5th most important issue is stated as "to find skilled employees in the areas of expertise that are increasingly needed", while the following responses were not seen as main challenges by the respondents: "Finding the right people in the right markets to realize our strategy and goals", "human resources processes and organizational processes and it has been determined that "carrying out strategies together", "the inadequacy of human resources processes in directing future generations", "creating proper and effective human resources". In other words, the participants stated that they would not have any difficulty in creating smooth and effective human resources processes in the next decade, and human resources processes would not be insufficient. As a result, while human resources managers consider themselves competent against structurally challenging issues in human resources, they stated that they would have difficulty in retaining and finding successful employees.

Figure 2 also shows Kruskal-Wallis test results in terms of the sector in which the participants operate. Accordingly, between the answers of "Developing leaders that will carry the company to the future", "staying competitive in the talent market", "creating smooth and effective business processes", "integrating human resources processes, organizational processes and 
strategies", "finding the right people in the right markets to realize our strategy and goals" and "the inadequacy of human resources processes in guiding future generations", no significant difference was found since the analysis values are higher than 0.05 in these subjects. In other words, similar degrees of importance are given without distinguishing the sectors.

Significant differences were found in terms of the sectors in which they operate, as these values are below 0.05 in the subjects of "retaining and rewarding the best employees", "creating an organizational culture that will attract the best employees to the organization" and "finding talented employees in the areas of expertise that are increasingly needed". Production companies gave different answers than other enterprises about "retaining and rewarding the best employees". The main reason for this can be given as the fact that production companies attract the best employees in every respect, and they are usually more generous in rewarding them. Public enterprises differ from enterprises in other sectors in terms of "creating an organizational culture that will attract the best employees to the organization". The reason for this can be said that there is a difference in public enterprises because the established organizational culture should be more stable and reliable. Public enterprises offer different views from other sector enterprises on the subject of "finding skilled employees in the areas of expertise that are increasingly needed". The main reason for this can be that public enterprises are preferred for providing more guarantee and securing job positions while working as a civil servant.

Figure 2 also shows the results of Kruskal-Wallis tests about responses for "retaining and rewarding the best employees", "creating an organizational culture that will attract the best employees", "staying competitive in the talent market", "our strategy and goals". Since the values are higher than 0.05 in the subjects of "finding the right people in the right markets to achieve realization", "conducting human resources processes and organizational processes and strategies together" and "the inadequacy of human resources processes in guiding future generations", no significant difference was found between the variables. In other words, similar degrees of importance are given without discriminating the field of activity.

Different responses were given to "developing leaders that will carry the company into the future" in terms of activity. International businesses gave different answers from regional and national businesses. The reason for this can be related to the high number of employees and the abundance of options. Regional businesses provided different answers than national and international enterprises to the question of "keeping skilled employees in the areas of expertise that are increasingly needed". The reason for this can be given regarding the movement of talented employees to larger enterprises. International businesses have responded differently from national and regional businesses to "creating smooth and effective human resources processes". The reason for this can be that international enterprises place more emphasis on design and development of human resources policies and practices.
Figure 3. Analysis by weight of the following areas that are planned to be invested in the next 10 years

\begin{tabular}{|c|c|c|c|c|c|c|c|}
\hline \multicolumn{4}{|c|}{$\begin{array}{l}\text { Investigation of the following areas planned to } \\
\text { be invested in the next } 10 \text { years in terms of } \\
\text { weight }\end{array}$} & \multirow{2}{*}{\begin{tabular}{|c|} 
Kruskal \\
Wallis \\
Test in \\
terms \\
of \\
industr \\
$y$ \\
\\
Chi- \\
Square \\
\end{tabular}} & \multirow{2}{*}{$\begin{array}{c}\text { Kruskal } \\
\text { Wallis Test in } \\
\text { terms of } \\
\text { industry }\end{array}$} & \multirow{2}{*}{$\begin{array}{c}\text { Kruskal } \\
\text { Wallis } \\
\text { Test in } \\
\text { terms } \\
\text { of field } \\
\text { of } \\
\text { activity } \\
\\
\text { Chi- } \\
\text { Square }\end{array}$} & \multirow{2}{*}{$\begin{array}{c}\text { Kruskal } \\
\text { Wallis Test in } \\
\text { terms of field } \\
\text { of activity }\end{array}$} \\
\hline $\begin{array}{c}\text { Specification } \\
\mathrm{S}\end{array}$ & $\begin{array}{c}\text { Averag } \\
\mathrm{e}\end{array}$ & $\begin{array}{c}\text { Kolmogoro } \\
\text { v Smirnov } \\
\text { Z Test }\end{array}$ & $\begin{array}{c}\text { Significanc } \\
\text { e Level }\end{array}$ & & & & \\
\hline $\begin{array}{l}\text { Human } \\
\text { capital } \\
\text { investments }\end{array}$ & 1.97 & 2.558 & 0.000 & 6.584 & 0.085 & 0.294 & 0.862 \\
\hline $\begin{array}{l}\text { Financial } \\
\text { capital } \\
\text { investments }\end{array}$ & 2.81 & 3.067 & 0.000 & 0.895 & 0.825 & 4.343 & 0.113 \\
\hline $\begin{array}{l}\text { Technologic } \\
\text { al capital } \\
\text { investments }\end{array}$ & 2.01 & 2.374 & 0.000 & 13.611 & 0.003 & 7.982 & 0.017 \\
\hline $\begin{array}{l}\text { Physical } \\
\text { capital } \\
\text { investments }\end{array}$ & 3.22 & 3.316 & 0.000 & 5.343 & 0.147 & 8.254 & 0.015 \\
\hline
\end{tabular}

Figure 3. shows the areas for investment in the next 10 years. One Sample Kolmogorov Smirnov Test was used to determine the priority order of the areas to be invested in the next 10 years. Based on the figures, the following comments can be made:

Participants stated that they give most importance to "human capital investments" in the next decade. Similarly, "technological capital investments" are seen as an important investment field. "Financial capital investments" and "physical capital investments" are regarded less important than human capital and technological capital investments. This is the proof of how important the human factor is for businesses parallel to importance given to keeping up with technology.

In Figure 3 the Kruskal-Wallis test results are also given. Responses about the areas considered to be invested in the next 10 years are given and a comparison is made of the sectors in which the businesses operate. As a result, there was no difference in the sectors "human capital investments", "financial capital investments" and "physical capital investments." However, there was a difference in "technological capital investments." Technological capital investments in the public sector seem to be less important, which can be due to the fact that technology transitions in public institutions take longer than private enterprises.

In Figure 3, the Kruskal-Wallis test results are also given, and the answers to the planned areas to be invested in the next ten years are compared with the business field of activity. As a result, HR managers' perspectives on "human capital investments" and "financial capital investments" do not differ in terms of their field of business activity. However, there was a difference in terms of activity area for "technological capital investments" and "physical capital investments". As for "technological capital investments", it is determined that regional enterprises give more importance to technological capital investments. We can connect this to desire of enterprises of growing and expanding their businesses. In terms of "physical capital investments", international enterprises have taken a different perspective as a field of activity. This can be attributed to the fact that international businesses prioritize investments. 
Figure 4. The tactics you will use most to attract, retain and reward the best employees in the next 10 years.

\begin{tabular}{|c|c|c|c|c|c|c|c|}
\hline \multicolumn{4}{|c|}{$\begin{array}{l}\text { Investigation of the following areas planned to be invested in } \\
\text { the next } 10 \text { years in terms of weight }\end{array}$} & \multirow{2}{*}{\begin{tabular}{|c|c}
$\begin{array}{c}\text { Kruska } \\
\text { IWallis } \\
\text { Test in } \\
\text { terms } \\
\text { of } \\
\text { industr } \\
y\end{array}$ \\
$\begin{array}{c}\text { Chi- } \\
\text { Square }\end{array}$ \\
\end{tabular}} & \multirow{2}{*}{$\begin{array}{c}\begin{array}{c}\text { Kruskal } \\
\text { Wallis Test } \\
\text { in terms of } \\
\text { industry }\end{array} \\
\begin{array}{c}\text { Expressivene } \\
\text { ss }\end{array}\end{array}$} & \multirow{2}{*}{$\begin{array}{c}\text { Krusk } \\
\text { al } \\
\text { Wallis } \\
\text { Testin } \\
\text { terms } \\
\text { of } \\
\text { field } \\
\text { of } \\
\text { activit } \\
\text { y } \\
\text { Chi- } \\
\text { Square }\end{array}$} & \multirow{2}{*}{$\begin{array}{c}\begin{array}{c}\text { Kruskal } \\
\text { Wallis Test } \\
\text { in terms of } \\
\text { field of } \\
\text { activity }\end{array} \\
\begin{array}{c}\text { Expressivene } \\
\text { ss }\end{array}\end{array}$} \\
\hline Specifications & $\begin{array}{c}\text { Averag } \\
\mathrm{e}\end{array}$ & \begin{tabular}{c|} 
Kolmogor \\
ov \\
Smirnovi Z \\
Test \\
\end{tabular} & $\begin{array}{l}\text { Significan } \\
\text { ce Level }\end{array}$ & & & & \\
\hline $\begin{array}{l}\text { To offer flexible working } \\
\text { arrangements }\end{array}$ & 4.48 & 1.278 & 0.075 & 2.091 & 0.552 & 0.048 & 0.975 \\
\hline $\begin{array}{l}\text { Creating open } \\
\text { communication, trust and a } \\
\text { fair culture }\end{array}$ & 3.73 & 1.608 & 0.012 & 3.342 & 0.343 & 1.933 & 0.382 \\
\hline $\begin{array}{l}\text { Offer higher total reward } \\
\text { packaces than competitiors }\end{array}$ & 6.17 & 2.462 & 0 & 6.712 & 0.081 & 0.031 & 0.984 \\
\hline $\begin{array}{l}\text { Demonstratet the importance } \\
\text { qiven to development }\end{array}$ & 3.92 & 1.495 & 0.022 & 0.484 & 0.921 & 2.214 & 0.332 \\
\hline $\begin{array}{l}\text { Providing meaningful work } \\
\text { consistent with the goals of } \\
\text { the organization }\end{array}$ & 5.93 & 1.861 & 0.002 & 6.425 & 0.092 & 2.195 & 0.334 \\
\hline $\begin{array}{l}\text { Creating a stimulating and } \\
\text { attractive organizational } \\
\text { culture }\end{array}$ & 5.03 & 1.207 & 0.107 & 2.745 & 0.431 & 3.863 & 0.146 \\
\hline $\begin{array}{l}\text { Employees to take risks and } \\
\text { encouraqe decision makina }\end{array}$ & 5.92 & 1.506 & 0.022 & 3.712 & 0.293 & 3.218 & 0.2 \\
\hline $\begin{array}{l}\text { To offer recognition and } \\
\text { reward consistent with the job } \\
\text { performance of employees }\end{array}$ & 5.18 & 1.347 & 0.052 & 2.562 & 0.463 & 0.756 & 0.684 \\
\hline $\begin{array}{l}\text { To provide opportunities that } \\
\text { employees can use in the } \\
\text { best way to present their } \\
\text { skills and capabilities }\end{array}$ & 4.62 & 2.678 & 0.017 & 5.675 & 0.127 & 2.685 & 0.262 \\
\hline
\end{tabular}

Responses revealed "Providing employees with recognition and reward consistent with their task performance" as a matter of little importance for the participants, "encouraging employees to take risks and making decisions" as an issue deemed unimportant, "presenting meaningful work consistent with the goals of the organization" as a less important issue. The option of "offering more total reward packages than competitors" was reported as a minor issue. As it can be understood from the responses, managers representing the enterprises think that they will not achieve much by offering more total reward packages. Participants also expressed an insignificant opinion on rewarding and risk taking.

The Kruskal-Wallis test results are also given in Figure 4 revealing whether the strategies used most in attracting, retaining and rewarding the best employees in the next decade differ in terms of the sector they operate in. As a result, it was determined that there was no difference in terms of the sector for any strategy and all sectors gave similar answers.

Figure 5. Human resources competencies considered to be most important in the next 10 years.

\begin{tabular}{|c|c|c|c|c|c|c|c|}
\hline \multicolumn{4}{|c|}{$\begin{array}{l}\text { Investigation of the following areas planned to be invested in the } \\
\text { next } 10 \text { years in terms of weight }\end{array}$} & \multirow{2}{*}{$\begin{array}{c}\text { Kruskal } \\
\text { Wallis } \\
\text { Testi in } \\
\text { terms of } \\
\text { industry } \\
\text { Chi- } \\
\text { Square }\end{array}$} & \multirow{2}{*}{$\begin{array}{c}\text { Kruskal Wallis } \\
\begin{array}{c}\text { Test in terms } \\
\text { of industry }\end{array} \\
\text { Expressiveness }\end{array}$} & \multirow{2}{*}{$\begin{array}{c}\text { Kruskal } \\
\text { Wallis } \\
\text { Testi in } \\
\text { terms } \\
\text { of field } \\
\text { of } \\
\text { activity } \\
\text { Chi- } \\
\text { Square }\end{array}$} & \multirow{2}{*}{$\begin{array}{c}\text { Kruskal Wallis } \\
\begin{array}{c}\text { Test in terms } \\
\text { of field of } \\
\text { activity }\end{array} \\
\text { Expressiveness }\end{array}$} \\
\hline Specifications & Average & $\begin{array}{c}\text { Kolmogorov } \\
\text { Smirnov Z } \\
\text { Test } \\
\end{array}$ & $\begin{array}{c}\text { Significance } \\
\text { Level }\end{array}$ & & & & \\
\hline job information & 4.41 & 1.986 & 0.001 & 0.521 & 0.913 & 13.882 & 0.001 \\
\hline $\begin{array}{l}\text { Organizational leadership and } \\
\text { guidance }\end{array}$ & 3.43 & 1.311 & 0.064 & 8.897 & 0.32 & 4.432 & 0.098 \\
\hline $\begin{array}{l}\text { To be reliable and } \\
\text { communication among } \\
\text { employees }\end{array}$ & 3.72 & 1.652 & 0.007 & 0.958 & 0.812 & 2.632 & 0.267 \\
\hline Being a strategic partner & 3.75 & 1.484 & 0.023 & 3.185 & 0.363 & 4.521 & 0.103 \\
\hline $\begin{array}{l}\text { Integrating human resources } \\
\text { technical knoviledge and } \\
\text { practices with technology }\end{array}$ & 4.52 & 1.557 & 0.015 & 9.945 & 0.018 & 2.055 & 0.357 \\
\hline $\begin{array}{l}\text { Managing the corporate } \\
\text { culture and providing } \\
\text { consultancy to the } \\
\text { organization in case of } \\
\text { possible changese. }\end{array}$ & 3.65 & 1.802 & 0.002 & 0.498 & 0.918 & 11.016 & 0.003 \\
\hline $\begin{array}{l}\text { To look at human resources } \\
\text { processes in an innovative } \\
\text { and intearative perspective. }\end{array}$ & 4.54 & 1.613 & 0.012 & 0.057 & 0.995 & 2.874 & 0.237 \\
\hline
\end{tabular}

The Kruskal-Wallis test results are displayed in Figure 4 showing whether the strategies used most in attracting, retaining and rewarding the best employees in the next decade differ in terms of their field of activity. As a result, it was determined that there was no difference in terms of field of activity for any strategy, and similar answers were received from all fields of business activities.

While managers and experts participating in the survey find "business knowledge" competency neither important nor insignificant, "integrating human resources technical knowledge and practices with technology" competence is regarded unimportant, and the option of "constantly looking at human resources processes in an innovative and integrative perspective" is reported as the least important by the participants.

In Figure 5, Kruskal-Wallis test results are also given, and it revealed whether the human resources competencies, which are thought to be the most important in the next decade, differ in terms of sectors or not. According to the results, there is a different perspective for the public sector in terms of "organizational leadership and guidance", and "integrating human resources technical knowledge and practices with technology". While they found "organizational leadership and guidance" more important than other sectors, they also leaned towards "integrating human resources knowhow and practices with technology" differently from other sectors. It is also found out that there is no difference in terms of the sector in other competencies than these, and all sectors provided similar answers.

Kruskal-Wallis test results of Figure 5 showed whether the human resources competencies, which are thought to be the most important in the next decade, differ in terms of the field of activity of the enterprises or not. In the light of the results, it is seen that there is a different perspective in terms of the competencies of "business knowledge" and "managing the corporate culture and guiding the organization in case of possible changes" for businesses working on a regional basis. While expressing their opinion that business knowledge is more important for regional enterprises compared to national and international enterprises, they have also reported a less important view on the competence of managing corporate culture and providing guidance to the organization in response to possible changes. Analysis results also showed that there is no other difference in competencies than these in terms of field of activity, and regional, national, and international enterprises give similar answers. 
Figure 6. Trend of sub-competencies in the concept of business knowledge competence in 10 years for HR managers

\begin{tabular}{|c|c|c|c|c|c|c|c|}
\hline \multicolumn{4}{|c|}{$\begin{array}{l}\text { Investigation of the following areas planned to be } \\
\text { invested in the next } 10 \text { years in terms of weight }\end{array}$} & \multirow{2}{*}{\begin{tabular}{|c|}
$\begin{array}{c}\text { Kruskal } \\
\text { Wallis } \\
\text { Test in } \\
\text { terms of } \\
\text { industry }\end{array}$ \\
$\begin{array}{c}\text { Chi- } \\
\text { Square }\end{array}$ \\
\end{tabular}} & \multirow{2}{*}{\begin{tabular}{|c|}
$\begin{array}{c}\text { Kruskal Wallis } \\
\text { Test in terms } \\
\text { of industry }\end{array}$ \\
Expressiveness
\end{tabular}} & \multirow{2}{*}{ 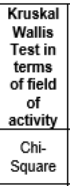 } & \multirow{2}{*}{$\begin{array}{c}\text { Kruskal Wallis } \\
\text { Test in terms } \\
\text { of field of } \\
\text { activity }\end{array}$} \\
\hline Specifications & Average & $\begin{array}{c}\text { Kolmogorov } \\
\text { Smirnov Z } \\
\text { Test } \\
\end{array}$ & \begin{tabular}{|c|}
$\begin{array}{c}\text { Significance } \\
\text { Level }\end{array}$ \\
\end{tabular} & & & & \\
\hline $\begin{array}{l}\text { HR analytics } \\
\text { metrics and } \\
\text { indicators }\end{array}$ & 4.02 & 1.608 & 0.01 & 0.398 & 0.942 & 0.231 & 0.89 \\
\hline $\begin{array}{l}\text { Operational and } \\
\text { logistics business } \\
\text { information }\end{array}$ & 6.7 & 1.261 & 0.083 & 8.665 & 0.033 & 2.433 & 0.487 \\
\hline Strategic agility & 4.22 & 1.761 & 0.003 & 4.507 & 0.211 & 3.384 & 0.142 \\
\hline $\begin{array}{l}\text { Industry, Market } \\
\text { and product } \\
\text { knowledge }\end{array}$ & 5.68 & 1.332 & 0.057 & 1.888 & 0.596 & 0.468 & 0.79 \\
\hline $\begin{array}{l}\text { Finance and } \\
\text { accounting } \\
\text { knovidedae }\end{array}$ & 7.03 & 1.747 & 0.004 & 1.16 & 0.761 & 6.224 & 0.043 \\
\hline $\begin{array}{l}\text { National and global } \\
\text { economic } \\
\text { awareness }\end{array}$ & 6.11 & 1.365 & 0.047 & 2.745 & 0.431 & 4.952 & 0.083 \\
\hline $\begin{array}{l}\text { Labor market } \\
\text { information }\end{array}$ & 6.22 & 0.976 & 0.295 & 0.588 & 0.898 & 0.256 & 0.876 \\
\hline $\begin{array}{l}\text { Technical and } \\
\text { technological } \\
\text { knoviledqe }\end{array}$ & 6.31 & 0.941 & 0.341 & 1.667 & 0.643 & 3.885 & 0.142 \\
\hline System thinking & 5.23 & 1.447 & 0.031 & 1.291 & 0.732 & 1.315 & 0.517 \\
\hline $\begin{array}{l}\text { Managing } \\
\text { processes } \\
\text { effectively }\end{array}$ & 5.45 & 1.408 & 0.037 & 5.1 & 0.164 & 5.243 & 0.072 \\
\hline $\begin{array}{l}\text { Sales and } \\
\text { marketing } \\
\text { information }\end{array}$ & 8.85 & 2.013 & 0.001 & 12.509 & 0.005 & 2.494 & 0.286 \\
\hline
\end{tabular}

In Figure 6, the data on the importance of the trend of the sub-competencies in the concept of business knowledge competence in ten years for human resources managers are shown. One Sample Kolmogorov-Smirnov Test was used to determine the order of importance of the tendency of the sub-competencies in the concept of business knowledge competence in terms of human resources managers within 10 years. Based on the analysis results, the following comments can be made:

Participants reported "human resources analytical metrics and indicators" as the most important issue regarding the sub-competencies of business knowledge competence. In other words, they stated that analytical indicators will be critically important in human resources field in the next decade. They emphasized "strategic agility" as the second most important issue while the 3rd most important issue was "systemic thinking", and the 4th one was "managing the processes effectively" according to the responses of the participants. The 5th important issue is given as "sector, market and product knowledge". "National and global economic awareness", "labour market knowledge" and "technical and technological knowledge" were determined as important issues, respectively. "Operational and logistics business knowledge" has been identified as a minor issue. As can be seen, sub-competencies of non-human-related external environment-related business information were determined to be less important, as well.

Participants identified "finance and accounting knowledge" as an insignificant competence, while nonessential competence was identified as "sales and marketing knowledge".

The Kruskal-Wallis test results are also given in Figure 6, and it revealed whether the tendency of the subcompetencies in the concept of business knowledge competence in ten years differs in terms of sectors for human resources managers. As a result, it has been determined that the answers given to the option "operational and logistics business information" are seen less important for the public sector. Apart from this, there are differences in the sectors regarding "sales and marketing information". The main reason for this can be given as the enterprises operating in the production and public sector are considered more important by the respondents, while the companies operating in the service and other sectors are considered less important. It has been determined that there is no difference between sectors regarding other competencies than these two, and all sectors provided similar answers.

The Kruskal-Wallis test results are also given in Figure 6 showing whether the tendency of the subcompetencies in the concept of business knowledge competence in ten years differs in the business activity field for human resources managers. Differences were only found in "finance and accounting" knowledge competence. The main reason of the difference can be due to the fact that regional businesses find it less important. It has been determined that there is no difference in the field of activity in other competencies than this competency as all sectors gave similar answers.

Figure 7. Human resources information contents for human resources managers in 10 years.

\begin{tabular}{|c|c|c|c|c|c|c|c|}
\hline \multicolumn{4}{|c|}{$\begin{array}{l}\text { Investigation of the following areas planned to be invested in } \\
\text { the next } 10 \text { years in terms of weight }\end{array}$} & \multirow{2}{*}{$\begin{array}{c}\text { Kruskal } \\
\text { Wallis } \\
\text { Test tin } \\
\text { tenss of } \\
\text { industry } \\
\text { Chi- } \\
\text { Square }\end{array}$} & \multirow{2}{*}{$\begin{array}{c}\begin{array}{c}\text { Kruskal Wallis } \\
\text { Test in terms } \\
\text { of industry }\end{array} \\
\text { Expressiveness } \\
\end{array}$} & \multirow{2}{*}{$\begin{array}{l}\text { Kruskal } \\
\text { Wallis } \\
\text { Test in } \\
\text { terms } \\
\text { of field } \\
\text { of } \\
\text { activity } \\
\text { Chi- } \\
\text { Square }\end{array}$} & \multirow{2}{*}{$\begin{array}{c}\text { Kruskal Wallis } \\
\text { Test in terms } \\
\text { of field of } \\
\text { activity }\end{array}$} \\
\hline Specifications & Average & $\begin{array}{l}\text { Kolmogorov } \\
\text { Smirnev Z } \\
\text { Test }\end{array}$ & $\begin{array}{l}\text { Significance } \\
\text { Level }\end{array}$ & & & & \\
\hline $\begin{array}{l}\text { Strategic business } \\
\text { knovidedoe }\end{array}$ & 3.68 & 1.956 & 0.001 & 5.937 & 0.114 & 0.535 & 0.764 \\
\hline Skill management & 3.42 & 1.917 & 0.001 & 8.665 & 2.108 & 3.951 & 0.138 \\
\hline Change management & 3.67 & 2.005 & 0.001 & 2.001 & 0.571 & 4.565 & 0.101 \\
\hline Workforce planning & 5.09 & 1.608 & 0.01 & 0.496 & 0.918 & 13.381 & 0.001 \\
\hline $\begin{array}{l}\text { Compensation and } \\
\text { benefits }\end{array}$ & 6.01 & 1.773 & 0.003 & 6.148 & 0.104 & 7.786 & 0.021 \\
\hline $\begin{array}{l}\text { Human resources } \\
\text { development }\end{array}$ & 5.03 & 1.346 & 0.052 & 4.76 & 0.191 & 1.126 & 0.568 \\
\hline $\begin{array}{l}\text { Organizing work and } \\
\text { labour relations }\end{array}$ & 6.33 & 1.762 & 0.003 & 6.015 & 0.112 & 2.181 & 0.335 \\
\hline $\begin{array}{l}\text { Continuous monitoring of } \\
\text { human resources } \\
\text { technologies }\end{array}$ & 5.97 & 1.683 & 0.006 & 1.975 & 0.576 & 15.947 & 0 \\
\hline $\begin{array}{l}\text { Establishment and } \\
\text { operation of numerical } \\
\text { metrics and analytics } \\
\text { related to human } \\
\text { resources }\end{array}$ & 5.65 & 1.551 & 0.015 & 4.311 & 0.231 & 0.217 & 0.896 \\
\hline
\end{tabular}

In Figure 7, data on the order of importance of human resources information contents for human resources managers are given. One Sample Kolmogorov-Smirnov Test was used to determine the order of importance of human resources information contents for human resources managers. Based on the figures, the following comments can be made:

Participants found the most important issue is "talent management" in terms of the contents of human resources information. They mentioned "change management" and "strategic business knowledge", respectively. As can be understood from the results, talent management will have an important place in terms of human resources in the next decade. Human resources managers regarded "human resources development" as the 4th important issue and "workforce planning" as the 5th important issue. As can be seen, these issues remained behind issues such as "talent management" and "change management".

The issues that human resources managers deem neither important nor insignificant are "establishment and operation of numerical metrics and analytics related to human resources" and "continuous monitoring of human resources technology". As unimportant issues, 
"remuneration and fringe benefits" were reported while the least important issues were reported as "regulation of labour and labour relations". In other words, human resources managers stated that compensation, fringe benefits and labour regulation issues are not more important than any other issues.

For the period of ten years later, it has been determined that there is no difference in terms of the sector in terms of the importance of human resources contents for human resources managers. In other words, similar answers were given without separating the sector. The Kruskal-Wallis test results are also given in Figure 7, and ten years later, in terms of the importance of human resources contents for human resources managers, three issues have been found important in terms of their field of activity. These include "workforce planning", "wages and benefits" and "continuous monitoring of human resources technology". It is seen that international enterprises express different views on workforce planning and assign more importance to it. It is observed that regional businesses attach less importance to wages and benefits. Regarding continuous monitoring of human resources technology, it is seen that regional enterprises express different opinions. This time, regional businesses have stated that the issue is more important. It has been determined that there is no difference in terms of field of activity in other competencies other than these subjects, and all sectors have given similar answers.

\section{Conclusion}

Some important findings have been obtained in line with the above literature review and the results of the survey conducted with the participants from Turkey. According to the human resources practitioners from the surveyed enterprises in Turkey, there are no significantly different human resources challenges expected in the future compared to the difficulties already experienced today. While the human resources literature generally focuses on how human resources departments should be positioned in the future, why and how human resources should be included in the general strategies of the business, and what roles human resources managers should play, human resources practitioners have emphasized the importance of the recruitment of better and talented personnel. The main reason behind this difference can be explained with the general business writing logic of the human resources literature that tries to generalize the obtained data in a particular country to be able to create a model that will fit everywhere and every time. Also, human resources literature, human resources departments and managers generally try to create some discourses and models that will legitimize them in line with the idea of they should be effective in high-level decisions and have a strong position within the company. Therefore, such efforts on HR issues are a common occurrence to maintain the legitimacy and effectiveness of the human resources field by generalizing the data they obtain in a specific and limited area.

In connection with the above reason, another reason for the difference between practitioners and the literature is the fact that the macro environment in which each business is located can be different from each other. In the literature, during the model creation processes, environmental effects were either ignored or the concept of environment was examined in general and abstract. Therefore, when we move the analysis level from the organization to the macro level, this difference may become more meaningful. Therefore, the results of the survey conducted in this direction may become significant if human resources are not evaluated in terms of how they are positioned in the business organizations, but instead by considering the fact that the recruitment of qualified manpower and its retainment were the key functions of the human resources department of the businesses participating in the study from Turkey. Of course, it should be emphasized that this conclusion may show differences from one business to another.

\section{References}

Aghazadeh, S. M. (2003). The future of human resource management. Work Study, 52(4), 201-207.

Amit, R., Belcourt. M. (2000). Human Resource Management Processes: A Value-Creating Source of Competitive Advantage, European Management Journal, 17(2), 174-181.

Amit, R., Shoemaker, J. H. (1993). Strategic assets and organizational rents. Strategic Management Journal, 14: 33-46.

Andersen, T. J., Minbaeva. D. (2013). The Role of Human Resource Management in Strategy Making, Human Resource Management, September-October, 52(5), 809827. https://doi.org/10.1002/hrm.21562

Armstrong, G. (2005). Differentiation Through people: How can $\mathrm{Hr}$ move beyond Business Partner, Human Resource Management, Vol.44, No.2, 195-199.

Beer, M. (1997). The Transformation of the Human Resource Function: Resolving the Tension between a Traditional Administrative and a New Strategic Role", Human Resource Management, Spring, 36(1), 49-56.

Becker, B., Gerhart, B. (1996). The Impact of Human Resource Management on Organizational Performance: Progress and Prospects. Academy of Management Journal, 39(4), 779-801.

Boston Consulting Group. (2010). The Future of HR in Europe: Key Challenges Through 2015, https://www.bcg.com/documents/file15033.pdf.

Boudreau, J. W., Ramstad. P. M. (2007). Beyond HR: The New Science of Human Capital, Boston: Harvard Business School Press.

Cascio, W. F. (2005). From Business Partner to Driving Business Success: The Next Step in the Evolution of HR Management, Human Resource Management, Summer, 44(2), 159-163.

Datta, D. K., Guthrie, J. P., Wright, P. M. (2005). Human Resource Management and Labor Productivity: Does Industry Matter? Academy of Management Journal, 48(1), 135-145.

Delery, J. E., Shaw, J. D. (2001). The strategic management of people in work organizations: Review, Synthesis and extension. In K. M. Rowland \& G. R. Ferris (Eds). Research in personnel and human resource management: 165-197. Greenwich, CT: JAI Press.

Fink, L. S., Longenecker. C. O. (2009). Creating human resource management value in challenging economic times, HR Advisor Journal, May/June,13-22.

Levine, D. (1995). Reinventing the workplace: How business and employers can both win. Washington, DC:Brookings Institution. 
Luthans, F., Youssef, C. M. (2004). Human, Social, and Now Positive Psychological Capital Management: Organizational Dynamics, 33(2), 143-160.

Pfeffer, J. (1998). The human equation: Building profits by putting people first, Boston: Harvard Business School Press.

Society for Human Resource Management. (2010). SHRM Foundation Leadership Roundtable: What is next for HR?, Philadelphia.

Stone, D. L., Deadrick, D. L. (2015). Challenges and opportunities affecting the future of human resource management. Human Resource Management Review, 25(2), 139-145. https://doi.org/10.1016/j.hrmr.2015.01.003

Ulrich, D., Brockbank. W. (2005). HR the Value Proposition, Mass., Boston: Harvard Business School Press.
Ulrich, D., Brockbank. W. (2009). The Role of Strategy Architect in Strategic HR Organization, People and Strategy, 32(1), 24-31.

Wright, P. M., Snell, S. A. (2005). Partner or Guardian? HR's Challenge in Balancing Value and Values, Human Resource Management, Summer, 44. 2nd ed.

Wright, P. M., Boswell, W. R. (2002). Desegregating HRM: A Review and Synthesis of Micro and Macro Human Resource Management Research. Journal of Management, 28(3), 247-276.

Ziskin, I., Boudreau. J. W. (2011). The future of HR and Effective Organizations, Organizational Dynamics, 40: 255-266.

Ayse Gunaltay, PhD Candidate, University of Miskolc - Hungary, Doctoral School of Enterprise Theory and Practice, Main research field is Business Management, Holder of a master's degree in Business and Administration - University of Miskolc, a.gunaltay1903@gmail.com, +36204398296

Ugur Filiz, PhD Candidate, Hungarian University of Agriculture and Life Sciences, Godollo - Hungary, Main research field: Doctoral School of Economic and Regional Sciences, Holder of a master's degree in Tourism Management - Budapest Business University, Holder of a master's degree in Political Science and Public Administration - Pamukkale University, filizuur@gmail.com, $+36302336986$ 
